\title{
Uji Aktivitas Antibakteri Dari Air Perasan Bawang Putih Terhadap Bakteri Salmonella Typhi
}

\author{
Olivia Yolanda Pasaribu ${ }^{1}$, Ade Pryta Simaremare ${ }^{2}$, Joseph Partogi Sibarani ${ }^{3}$ \\ ${ }^{1}$ Mahasiswa, Fakultas Kedokteran Universitas HKBP Nommensen \\ 2 Departemen Mikrobiologi Fakultas Kedokteran Universitas HKBP Nommensen \\ ${ }^{3}$ Departemen IImu Penyakit Dalam Fakultas Kedokteran Universitas HKBP Nommensen \\ Korespondensi: Olivia Yolanda Pasaribu, Email: yolandao4141@gmail.com
}

\begin{abstract}
Background: Garlic is a plant which is used to treat various types of diseases, especially the ones caused by bacterial infection. Allicin in garlic is one of the active compounds which has an antibacterial effect. Some studies found that garlic has an inhibitory effect on Salmonella typhi.
\end{abstract}

Objective: This study aimed to determine the antibacterial effect of garlic juice against Salmonella typhi.

Method: This study was an experimental-laboratory research using disc diffusion method on MHA media. This study used five concentrations, namely 12.5\%, 25\%,50\%,75\%, and 100\%. Amoxicillin and aquadest were used as positive and negative controls. The inhibition zone was determined by observing the clear zone around the disc then the results of the study were compared with positive control with CLSI 2017 guidance table where Salmonella typhi was susceptible when the amoxicillin inhibitory diameter zone was $\geq 17 \mathrm{~mm}$, intermediate was $14-16 \mathrm{~mm}$, and resistant was $\leq 13 \mathrm{~mm}$.

Results: The results showed that garlic juice has an antibacterial effect on various consentration. The minimum concentration of garlic juice to inhibit the growth of Salmonella typhi is on 50\% with $19.25 \mathrm{~mm}$ diameters.

Conclusion: There was an antibacterial effect of garlic juice on Salmonella typhi.

Keywords: Garlic juice, Salmonella typhi, antibacterial

\begin{abstract}
Abstrak
Latar belakang: Bawang putih merupakan salah satu tanaman yang digunakan untuk mengobati berbagai jenis penyakit, salah satunya penyakit yang disebabkan oleh infeksi bakteri. Bawang putih memiliki senyawa Allicin yang memiliki efek antibakteri. Beberapa penelitian menyebutkan bahwa bawang putih memiliki daya hambat terhadap pertumbuhan Salmonella typhi.
\end{abstract}

Tujuan: Penelitian ini bertujuan untuk mengetahui aktivitas antibakteri dari air perasan bawang putih terhadap bakteri Salmonella typhi.

Metode: Penelitian ini adalah penelitian eksperimental-laboratorik dengan metode difusi cakram menggunakan media MHA. Penelitian ini menggunakan lima konsentrasi yaitu 12,5\%, 25\%,50\%,75\%, dan 100\%. Kontrol positif dan negatif yang digunakan dalam penelitian ini yaitu amoxicillin dan aquades. Zona hambat ditentukan dengan mengamati zona bening yang terbentuk di sekeliling cakram kemudian hasil penelitian dibandingkan dengan kontrol positif dengan panduan tabel CLSI 2017 di mana untuk Salmonella typhi dikatakan susceptible bila diameter zona hambat amoxicillin sebesar $\geq 17 \mathrm{~mm}$, intermediate $14-16 \mathrm{~mm}$, dan resistant $\leq 13 \mathrm{~mm}$.

Hasil: Hasil penelitian menunjukkan bahwa pada berbagai konsentrasi air perasan bawang putih didapatkan air perasan bawang putih memilliki efek antibakteri. Konsentrasi minimum dari air perasan bawang putih untuk menghambat pertumbuhan Salmonella typhi adalah pada konsentrasi 50\% dengan nilai 19,25 mm. 
Kesimpulan: Terdapat aktivitas antibakteri dari air perasan bawang putih dalam menghambat pertumbuhan bakteri Salmonella typhi.

\section{Kata Kunci: Air perasan bawang putih, Salmonella typhi, antibakteri}

\section{Pendahuluan}

Penyakit infeksi merupakan penyakit yang paling tua yang masih menjadi masalah kesehatan utama di negara berkembang maupun di negara maju. Menurut WHO (World Health Organization) penyakit infeksi adalah penyakit yang disebabkan oleh mikroorganisme patogen seperti virus, jamur, parasit, dan bakteri. ${ }^{1}$ Salah satu bakteri yang merupakan patogen utama manusia adalah Salmonella typhi. ${ }^{2}$

Salmonella typhi merupakan bakteri penyebab penyakit demam tifoid. Penyakit ini biasanya menyebar melalui ingesti makanan dan air yang tercemar.3,4 Menurut data World Health Organization (WHO) tahun 2018, kasus demam tifoid diperkirakan berkisar antara 11-21 juta dan sekitar 128.000 hingga 161.000 kematian terkait demam tifoid terjadi setiap tahunnya di seluruh dunia. Mayoritas kasus terjadi di Asia Selatan/Tenggara, dan Afrika SubSahara. ${ }^{5}$

Penyakit demam tifoid dapat disembuhkan dengan pengobatan menggunakan antibiotik. Antibiotik yang digunakan sebagai pengobatan demam tifoid harus dapat ditoleransi oleh pasien, dapat mencapai kadar tinggi pada usus, serta memiliki spektrum yang terbatas untuk beberapa bakteri. Beberapa antibiotik yang biasa digunakan adalah chloramphenicol, amoxicillin, ciprofloxacin, gentamicin, dan cotrimoxazole. Chloramphenicol saat ini masih merupakan pilihan utama untuk pengobatan demam tifoid. Selain chloramphenicol, amoxicillin juga merupakan salah satu antibiotik yang dianjurkan untuk mengobati penyakit yang disebabkan oleh bakteri ini karena relatif murah, lebih toleran, dan lebih cepat menimbulkan efek yang baik. Sifat kerja dari amoxicillin adalah mencegah terbentuknya membran sel bakteri sehingga materi genetik yang ada di dalamnya terurai keluar dan menyebabkan bakteri mati. ${ }^{6}$

Pemakaian antibiotik harus tepat indikasi, tepat penderita, tepat obat, tepat dosis, dan waspada efek samping obat. Pemakaian antibiotik yang tidak tepat akan menyebabkan munculnya banyak efek samping dan mendorong munculnya bakteri yang resisten terhadap antibiotik tersebut. ${ }^{7}$ Untuk menanggulangi masalah tersebut, maka penggunaan obat-obat alami berbahan dasar tumbuhan menjadi jalan alternatif.

Beberapa penelitian menunjukkan bahwa bawang puth dapat menghambat pertumbuhan bakteri, ${ }^{8-10}$ salah satunya adalah bakteri Salmonella typhi. Penelitian yang dilakukan oleh Nadifah membuktikan bahwa konsentrasi minimum air perasan bawang puth dalam menghambat pertumbuhan Salmonella typhi adalah pada konsentrasi $20 \%$ yang artinya air perasan bawang puth memiliki efektivitas antibakteri terhadap Salmonella typhi. ${ }^{11}$ Ketika bawang putih dimemarkan atau dihaluskan, zat alliin yang tidak berbau akan terurai menjadi allicin. Allicin diduga mempunyai efek antibakteri yang kuat.9,12

Pada penelitian sebalumnya, Nadifah menggunakan konsentrasi perasan bawang putih $20 \%$ sebagai kontrol positifnya. ${ }^{11}$ Penelitian ini menggunakan amoxicillin sebagai kontrol positifnya, di mana amoxicillin merupakan salah satu antibiotik yang digunakan untuk mengobati penyakit yang disebabkan oleh bakteri Salmonella typhi. ${ }^{6}$ Kontrol positif amoxicillin menjadi pembanding aktivitas antibakteri pada beberapa konsentrasi air perasan bawang putih terhadap bakteri yang akan diuji.

Tujuan dilakukannya penelitian ini adalah untuk mengetahui aktivitas antibakteri dari air perasan bawang putih terhadap bakteri Salmonella typhi.

\section{Metode}

Penelitian ini merupakan penelitian eksperimental-laboratorik dengan metode difusi cakram menggunakan media MHA. Penelitian ini dilakukan di Laboratorium Mikrobiologi Fakultas Kedokteran Universitas HKBP Nommensen. Bakteri yang digunakan dalam penelitian ini adalah bakteri Salmonella typhi yang dikultur dalam media agar McConkey. Penelitian ini melakukan pengulangan sebanyak 3 kali menggunakan rumus Federer, kemudian diambil rata-ratanya untuk memperoleh hasil yang valid. Bahan uji yang digunakan dalam penelitian ini adalah bawang putih (Allium sativum) dalam bentuk air perasan yang dibuat dalam beberapa konsentrasi yaitu konsentrasi $12,5 \%, 25 \%$, $50 \%, 75 \%$, dan $100 \%$. Penelitian ini menggunakan kontrol positif dan negatif yaitu masing-masing amoxicillin dan aquades. Alat dalam penelitian ini disterilisasi terlebih dahulu dengan cara dicuci bersih, kemudian dimasukkan kedalam autoklaf selama 15 menit dengan suhu $121^{\circ} \mathrm{C}$. Kemudian bawang putih ditimbang sebanyak 500 gram, dikupas, dibersihkan, dan diperas dengan menggunakan alat juice extractor sehingga diperoleh air perasan bawang puth $100 \%$. Hasil perasan ditampung, kemudian dibuat konsentrasi $12,5 \%, 25 \%, 50 \%$, dan $75 \%$ dengan pengenceran menggunakan aquades yang akan dibuat dalam $10 \mathrm{ml}$ dalam tabung reaksi. Ke dalam masing-masing konsentrasi air perasan bawang putih tersebut direndamkan cakram kosong selama 30 menit.

Pembuatan suspensi bakteri Salmonella typhi dengan cara bakteri Salmonella typhi di homogenisasi dengan mengambil 1 ose bakteri dan dimasukkan ke dalam tabung reaksi yang sudah diisi dengan $\mathrm{NaCl} 0,9 \%$. Kemudian kekeruhannya disamakan dengan larutan Mc Farland 0,5 untuk mendapatkan bakteri sebanyak 1,5 x $10^{8}$ $\mathrm{CFU} / \mathrm{ml}$.

Suspensi Bakteri Salmonella typhi diambil dengan pipet sebanyak $1 \mathrm{ml}$ dan diteteskan ke media Muller Hinton Agar (MHA) dalam cawan petri dan diratakan dengan menggunakan ose. Kertas cakram kosong yang sudah direndam dalam masing-masing konsentrasi air perasan bawang putih selama 30 menit diletakkan di atas media agar. Pada media ditambahkan 1 kertas cakram amoxicillin sebagai kontrol positif dan 1 kertas cakram yang telah direndam aquades selama 30 menit sebagai kontrol negatif. Kemudian kedua media diinkubasi dalam inkubator selama 24 jam dengan suhu $37^{\circ} \mathrm{C}$. Setelah 24 jam, kedua media dikeluarkan dari inkubator dan diukur zona hambatnya menggunakan penggaris. 
Zona hambat ditentukan dengan mengamati zona bening yang terbentuk di sekeliling cakram.

\section{Hasil}

Penelitian ini menggunakan metode agar disk-diffusion dengan konsentrasi air perasan bawang putih masing-masing 12,5\%, 25\%, $50 \%$, 75\%, 100\%. Penelitian ini melakukan pengulangan menggunakan rumus Federer sehingga didapatkan pengulangan dilakukan sebanyak 3 kali. Hasil dari ketiga pengulangan tersebut diambil nilai rata-ratanya untuk mendapatkan hasil yang valid. Hasil penelitian kemudian dibandingkan dengan kontrol positif dengan panduan tabel CLSI 2017 di mana untuk Salmonella typhi dikatakan susceptible bila diameter zona hambat amoxicillin sebesar $\geq 17 \mathrm{~mm}$, intermediate $14-16 \mathrm{~mm}$, dan resistant $\leq 13$ $\mathrm{mm} .{ }^{13}$

Hasil diameter zona hambat air perasan bawang putih terhadap bakteri Salmonella typhi telah dirangkum dalam Tabel 1. Berdasarkan hasil penelitian yang telah dilakukan didapat hasil susceptible pada amoxicillin dengan diameter $31,75 \mathrm{~mm}$ yang artinya masih efektif bekerja membunuh bakteri Salmonella typhi. Bila dibandingkan dengan kontrol positif, pada konsentrasi air perasan bawang putih $100 \%$, $75 \%$, dan $50 \%$ didapat hasil susceptible karena terbentuk zona hambat $\geq 17 \mathrm{~mm}$. Konsentrasi minimum air perasan bawang putih dalam menghambat pertumbuhan Salmonella typhi secara optimal adalah pada konsentrasi $50 \%$, sedangkan pada konsentrasi $25 \%$ didapat hasil antara intermediate dan resistant, berarti kemampuannya kurang efektif tetapi masih dapat menghambat dengan daya yang rendah. Pada konsentrasi 12,5\% didapat hasil resistant karena ukuran zona hambat $\leq 13 \mathrm{~mm}$.

Tabel 1. Hasil Diameter Zona Jernih Rata-rata Air Perasan Bawang Putih Terhadap Bakteri Salmonella Typhi

\begin{tabular}{ccc}
\hline Kertas Cakram & $\begin{array}{c}\text { Diameter Zona } \\
\text { Hambat Rata-rata } \\
(\mathbf{m m})\end{array}$ & Interpretasi \\
\hline Amoxicillin & 31,75 & Susceptible \\
Aquades & - & - \\
$\begin{array}{c}\text { Air perasan } \\
\text { bawang puth } \\
\quad 100 \%\end{array}$ & 30,0 & Susceptible \\
$\begin{array}{c}\text { Air perasan } \\
\text { bawang putih 75\% } \\
\text { Air perasan }\end{array}$ & 25,5 & Susceptible \\
bawang putih 50\% \\
$\begin{array}{c}\text { Air perasan } \\
\text { bawang putih 25\% } \\
\text { Air perasan } \\
\text { bawang puth } \\
\text { 12,5\% }\end{array}$ & 19,25 & Susceptible \\
\hline
\end{tabular}

\section{Pembahasan}

Bakteri Salmonella typhi merupakan bakteri yang termasuk ke dalam golongan bakteri gram negatif, di mana dinding sel bakteri terdiri atas membran plasma, lapisan peptidoglikan tipis, dan membran luar yang mengandung lipopolisakarida (endotoksin). Lipopolisakarida bertanggung jawab atas aktivitas endotoksin nonspesifik pada bakteri gram negatif. Dinding sel bersifat permeabel non-selektif, akan tetapi membran luar menghalangi masuknya molekul-molekul yang relatif besar. Dalam kelangsungan hidupnya, DNA, RNA, dan protein memegang peranan yang sangat penting dalam proses kehidupan sel. ${ }^{14}$

Allicin merupakan komponen yang terkandung dalam bawang putih, ketika bawang putih dipotong atau dihancurkan, maka enzim alliinase akan aktif dan mengubah alliin menjadi allicin. ${ }^{7}$ Kemampuan bawang putih dalam menghambat pertumbuhan bakteri disebabkan kandungan allicin yang terdapat di dalam bawang putih. Daya hambat yang dihasilkan oleh air perasan bawang putih terhadap pertumbuhan bakteri Salmonella typhi dapat terjadi karena beberapa proses yang melibatkan kandungan senyawa sulfur yang larut dalam lemak bawang putih seperti allicin dan hasil uraian lainnya dialil sulfide (DAS), dialil disulfide (DADS), diallytrisulphide (DATS). Allicin dan hasil uraiannya berhasil berpenetrasi menembus dinding sel bakteri, mengikat asam amino dan protein sehingga menyebabkan gangguan pada metabolisme Salmonella typhi. 15,16

Penelitian mengenai aktivitas antibakteri perasan umbi bawang putih (Allium sativum Linn.) terhadap pertumbuhan bakteri Salmonella typhi secara in vitro yang dilakukan oleh Nadifah menyatakan bahwa bakteri Salmonella typhi peka terhadap air perasan bawang putih dengan diameter zona hambat 45,3 mm pada konsentrasi $100 \%$. Hasil penelitian Nadifah menunjukkan bahwa semakin tinggi konsentrasi air perasan bawang putih maka semakin besar pula zona hambat yang terbentuk. ${ }^{11}$ Penelitian yang dilakukan oleh Vinenthy dengan konsentrasi air perasan bawang putih 20\%, 40\%, 60\% dan $80 \%$ memiliki kemampuan dalam menghambat pertumbuhan Salmonella typhi. Menurut Vinenthy, proses pemerasan yang dilakukan menyebabkan terjadinya perubahan struktur fisik dari bawang putih, sehingga senyawa aktif yang terkandung dalam bawang putih menjadi terurai. ${ }^{17}$

Allicin dapat menghambat proliferasi bakteri, jamur, atau membunuh sel secara langsung. Allicin memblok sintesis DNA (timidin), RNA (urasil), dan protein (leusina). ${ }^{18}$ Allicin pada bawang putih mempunyai aktivitas antibakteri yang menyerang bakteri gram positif maupun gram negatif. Senyawa allicin dapat meningkatkan permeabilitas dinding bakteri, ketika terjadi peningkatan permeabilitas pada dinding bakteri, gugus $\mathrm{SH}$ (sulfihidril dan disulfida) pada asam amino sistin dan sistein hancur. Gugus SH yang hancur mengakibatkan sintesis enzim protease terhambat dan membran sitoplasma pada dinding bakteri rusak, serta terganggunya metabolisme protein dan asam nukleat sehingga tidak terjadi proliferasi pada bakteri. ${ }^{19}$ Allicin juga menyerang DNA, RNA dan sintesis protein, target utama allicin adalah RNA. ${ }^{11,16}$ Menurut Murungan, ketika RNA tidak bisa diproduksi, atau diproduksi dalam jumlah kurang, maka protein sintesis akan sangat terpengaruh karena tidak adanya messenger RNA (mRNA), ribosom RNA (rRNA), dan transfer RNA (tRNA). Jika asam amino dan protein tidak dapat diproduksi maka tidak akan terjadi pertumbuhan dan perkembangan bakteri. ${ }^{20}$

Selain allicin terdapat beberapa senyawa yang juga bekerja dalam penghambatan bakteri yaitu senyawa alkaloid, dan flavonoid. Senyawa alkaloid memiliki gugus basa nitrogen yang akan mengalami reaksi saat mengalami kontak dengan senyawasenyawa asam amino dan juga DNA bakteri, sehingga sel bakteri 
menjadi lisis. ${ }^{21,22}$ DNA merupakan penyusun utama inti sel dan merupakan pusat pengaturan segala kegiatan sel. Senyawa flavonoid bekerja dengan cara merusak dinding sel bakteri yang terdiri atas lipid dan asam amino, sehingga dinding sel akan rusak dan senyawa flavonoid akan masuk ke dalam inti sel bakteri dan terjadi reaksi di mana struktur DNA bakteri akan rusak dan inti sel bakteri juga akan lisis. ${ }^{22}$ Penelitian ini masih memiliki banyak keterbatasan. Semua yang dilakukan harus selalu dalam kondisi yang steril. Bagi peneliti selanjutnya agar dapat meneliti perbedaan efek antimikroba yang terkandung dalam bawang putih menggunakan berbagai cara ekstraksi selain dengan cara perasan. Dapat dilakukan penelitian mengenai aktivitas antimikroba bawang putih terhadap Salmonella typhi secara in vivo. Diharapkan peneliti selanjutnya untuk melakukan pengukuran kadar aktif yang terkandung dalam bawang putih.

\section{Kesimpulan}

Terdapat aktivitas antibakteri dari air perasan bawang putih terhadap bakteri Salmonella typhi. Konsentrasi minimum air perasan bawang putih untuk dapat menghambat pertumbuhan bakteri Salmonella typhi secara optimal adalah pada konsentrasi $50 \%$ yaitu dengan diameter zona hambat $19,25 \mathrm{~mm}$.

\section{Ucapan Terima Kasih}

Peneliti mengucapkan terima kasih kepada Universitas HKBP Nommensen yang telah memberikan kesempatan kepada peneliti untuk melakukan dan menyelesaikan penelitian ini.

\section{Daftar Pustaka}

1. World Health Organization (WHO). Infectious Diseases [Internet]. World Health Organization (WHO). Available from: https://www.who.int/topics/infectious_diseases/en/

2. Tong SYC, Davis JS, Eichenberger E, Holland TL, Fowler VG Staphylococcus aureus infections: epidemiology, pathophysiology, clinical manifestations, and management. Am Soc Microbiol. 2015;28(3):605-35.

3. Ashurst J V, Truong J, Woodbury B. Salmonella Typhi [Internet]. StatPearls. NCBI; $2020 . \quad$ p. 1-9. Available from: https://www.ncbi.nlm.nih.gov/books/NBK519002/

4. Alba S, Bakker MI, Hatta M, Scheelbeek PF, Dwiyanti R, Usman R, et al. Risk factors of typhoid infection in the Indonesian Archipelago. [Internet]. NCBI. $2016 . \quad$ Available from: https://www.ncbi.nlm.nih.gov/pubmed/27281311

5. World Health Organization (WHO). Weekly epidemiological record. World Health Organization (WHO). 2018 Mar 30;
6. Sandika J, Suwandi JF. Sensitivitas Salmonella thypi penyebab demam tifoid terhadap beberapa antibiotik. Majority. 2017;6(1):41-5.

7. Jeanna S. Antibacterial activity of garlic (Allium sativum I.). Fac Med Univ Lampung. 2015;4.

8. Hapsoh, Hasanah Y. Budidaya Tanaman Obat dan Rempah. Medan: USU Press; 2011. $192 \mathrm{p}$.

9. Pajan SA, Waworuntu O, Leman MA. Potensi antibakteri air perasan bawang putih (Allium sativum $L$ ) terhadap pertumbuhan Staphylococcus aureus. Pharmacon J IIm Farm. 2016;5(4):77-89.

10. Irmudita RA, Margawati DH. Uji aktivitas antibakteri ekstrak bawang putih (Allium sativum Linn) terhadap bakteri Escherichia coli in vitro [skripsi]. Universitas Diponegoro. 2008.

11. Nadifah $F$, Prasetyaningsih $Y$, Masithah RA. Aktivitas antibakteri perasan umbi bawang putih (Allium sativum Linn.) terhadap pertumbuhan bakteri Salmonella typhi secara in vitro. Biomedika. 2016;9(1).

12. Bayan L, Koulivand PH, Gorji A. Garlic: a review of potential therapeutic effects. Avicenna J Phytomed [Internet]. 2014;4(1):1-14.

13. CLSI. Performance Standards for Antimicrobial Susceptibility Testing. 27th ed. Clinical and Laboratory Standards Institute; 2017.

14. Carroll KC, Morse SA, Mietzner T, Miller S. Jawetz, Melnick, \& Adelberg. Mikrobiologi Kedokteran. 27th ed. Allen., Handoko C, Hariyanto RB, Sadikin RE, Agustin S, Sonia., et al., editors. Jakarta: EGC; 2016. 215 p.

15. Mikaili P, Maadirad S, Moloudizargari M, Aghajanshakeri S, Sarahroodi S. Therapeutic uses and pharmacological properties of garlic, shallot, and their biologically active compounds. Iran J Basic Med Sci. 2013; 16(10):1031-48.

16. Mun'im A, Hanani E. Fitoterapi Dasar. 1st ed. Jakarta: Dian Rakyat; 2011. 28-35 p.

17. Vinenthy LPIV, Habibah N, Dhynaputri IGAS. Uji Daya Hambat perasan bawang putih terhadap pertumbuhan Salmonella typhi. J Kesehat. 2019;10(3):354-9.

18. Borlinghaus J, Albrecht F, Gruhlke MCH, Nwachukwu ID, And, Slusarenko AJ. Allicin: chemistry and biological properties. Molecules. 2014;12591-618.

19. Purwantiningsih TI, Rusae A, Freitas Z. Uji in vitro antibakteri ekstrak bawang putih sebagai bahan alami untuk menghambat bakteri Staphylococcus aureus dan Escherichia coli. Sains Perternakan. 2019;17(1):1-4.

20. Murungan SM, Chaturvedi VK, Karthink K, Bincy J, Sunitha C, Sumithra TG, et al. Antibacterial effect of garlic (Allium sativum) on Salmonella serovars: An in vitro study. Merit Res. 2015;3(1):6-8.

21. Soraya C, Chismirina S, Novita R. Pengaruh perasan bawang putih (Allium sativum L.) sebagai bahan irigasi saluran akar dalam menghambat pertumbuhan Enterococcus faecalis secara in vitro. Cakradonya Dent $\mathrm{J}$. 10(1):1-9.

22. Komala O, Asmara HI, Wiendarlina IY. Uji efektivitas antibakteri perasan segar dan serbuk umbi bawang putih (Allium sativum L.) terhadap bakteri Salmonella typhi. Ekologia. 2014;14(2):34-9. 